\title{
Assessment of Oriçanga and Itupeva rivers water quality at the Pardo-Mogi watershed (Sáo Paulo State, Brazil)
}

\author{
Avaliação da qualidade da água dos rios Oriçanga e Itupeva na \\ bacia dos rios Pardo-Mogi (Estado de São Paulo, Brasil)
}

Mariana Silveira-Guerra Moura e Silva ${ }^{1}$, Julio Ferraz de Queiroz ${ }^{1}$, Roberto Cesnik ${ }^{1}$,

José Maria Guzman Ferraz ${ }^{1}$, Jener Fernandes Moraes $^{2}$

${ }^{1}$ Laboratório de Ecossistemas Aquáticos, Embrapa Meio Ambiente,

Rod. SP 340, Km 127,5 Bairro Tanquinho Velho, CEP 13120-000, Jaguariúna, SP, Brazil

e-mail: silveiramariana@yahoo.com.br, jqueiroz@cnpma.embrapa.br, rcesnik@hotmail.com, ferraz@cnpma.embrapa.br

${ }^{2}$ Instituto Agronômico de Campinas, Av. Barão de Itapura, 1481, CP 28, CEP 13020-902, Campinas, SP, Brazil, e-mail: jfmoraes@iac.sp.gov.br

\begin{abstract}
Aims: This study aimed to assess the impacts of anthropic activities at four sites of two rivers from the Mogi-Guaçu watershed in São Paulo State, Brazil; Methods: Sites were classified according to their environmental integrity, based on the index developed by Callisto et al. (2002). Physico-chemical and biotic metrics were measured bimonthly. Principal Component Analysis (PCA) analysis was used to assess the relationship between sites and samples. Measures of soil loss evaluated the impacts from land uses at the Mogi-Guaçu watershed; Results: Fifty-two macroinvertebrate families were identified at Oriçanga and Itupeva rivers. The Calamoceratidae (Trichoptera) are shredders, and their percentage was greatest at the most preserved site, where the riparian forest was in good condition. Some unexpected results were found at (ORIC 1), considered a minimally disturbed site according to a Rapid Assessment Protocol. At this site, family richness and Shannon-Weaver diversity index were both low, which could be attributed to riparian forest deforestation, resulting in less aquatic biodiversity. Principal Component Analysis (PCA) showed differences in physico-chemical parameters and macroinvertebrate families, but these differences were not so evident to separate sites according to their environmental integrity degree; Conclusions: We conclude that water quality seemed to be related to land use, as soil losses prevailed in pasture and sugar cane areas, where water quality parameters (biotic and physico-chemical) showed worse results. And that land uses must consider the slope of areas near aquatic ecosystems, due to the potential environmental impacts to these systems, especially erosion and inflow of polluted effluents.
\end{abstract}

Keywords: biomonitoring, water quality, Mogi-Guaçu watershed, soil loss.

Resumo: Objetivo: Este estudo teve como objetivo avaliar os impactos de atividades antrópicas em quatro pontos de coleta de dois rios da bacia do rio Mogi-Guaçu no Estado de São Paulo, Brasil; Métodos: Os locais foram classificados de acordo seu nível de integridade ambiental, baseado no índice desenvolvido por Callisto et al. (2002). Bimensalmente, foram medidos parâmetros físico-químicos e biológicos. A Análise de Componentes Principais (ACP) avaliou a relaçáo entre locais e amostras. Medidas de perda de solo avaliaram os impactos do uso da terra na bacia estudada; Resultados: Foram identificadas cinqüenta e duas famílias de macroinvertebrados em ambos os rios Oriçanga e Itupeva. A família Calamoceratidae (Trichoptera), composta por fragmentadores, teve maior porcentagem no local mais preservado da mata ripária. Contrariando o esperado, o ponto de coleta ORIC 1, considerado pouco perturbado de acordo com o Protocolo de Avaliaçáo Rápida, apresentou baixos valores para riqueza de famílias e índice de diversidade de Shannon-Weaver, o que pode ser atribuído à retirada da mata ripária, resultando em uma menor biodiversidade aquática. A Análise de Componentes Principais (ACP) mostrou diferenças entre parâmetros físico-químicos e famílias de macroinvertebrados, mas estas diferenças não foram táo evidentes a ponto de diferenciar os locais de coleta de acordo com o seu nível de integridade ambiental; Conclusóes: A qualidade da água pareceu estar relacionada com o uso da terra, pois a perda de solo prevaleceu em áreas de pastagem e cultura de cana-de-açúcar, onde os 
parâmetros bióticos e físico-químicos de qualidade de água estavam em pior condição. $\mathrm{E}$ ainda, os usos da terra devem considerar a inclinação de áreas próximas aos ecossistemas aquáticos, devido ao potencial de impacto ambiental, especialmente de erosão e entrada de efluentes poluentes.

Palavras-chave: biomonitoramento, qualidade de água, bacia do rio Mogi-Guaçu, perda de solo.

\section{Introduction}

The structure of benthic macroinvertebrate assemblages is shaped by many factors, such as stream hydraulics, substratum, water chemistry, and riparian vegetation (Minshall, 1984; Richards et al., 1997). On the other hand, landscape-level factors such as land-use/cover, superficial geology, and surface area, or geographic factors such as latitude and distance to river head, may be more important than within-stream characteristics (Roth et al., 1996).

The conversion of forests into pasture or other land uses may modify in-stream habitat and macroinvertebrate communities in several ways, leading to major shifts in benthic community structure and declines in macroinvertebrate diversity (Iwata et al., 2003; Dudgeon, 2006; Wantzen, 2006).

Increased solar radiation due to deforestation of riparian forests changes water temperature, primary production and oxygen diffusion. Furthermore, sediment inputs to streams can alter sediment characteristics and channel morphology, often reducing macroinvertebrate diversity (Waters, 1995; Quinn et al., 1997). Vasconcelos and Melo (2008) found that even short-term inputs can cause disturbances in macroinvertebrate communities, and called attention to the need for adequate land use management in tropical catchments.

The mosaic created by different land uses, especially agriculture and pasture, contributed to deforestation of riparian vegetation, which have caused severe impacts on the hidric resources of the adjacent areas, and consequently, on the aquatic fauna (Corbi and Trivinho-Strixino, 2006).

Anthropogenic forest fragmentation also plays an important role in changes to stream macroinvertebrate communities. Harding et al. (2006) found that taxonomic richness, Margalef's index and numbers of Ephemeroptera, Plecoptera and Trichoptera (EPT) were significantly higher in continuous forest than in forested fragment sites, but overall invertebrate densities did not differ between fragments and continuous forest. For physico-chemical parameters, electric conductivity and water temperature were higher near agricultural activities or forest fragment sites. Lorion and Kennedy (2009) compared macroinvertebrate communities in different stream situations in Costa Rica and found that deforestation - even at a very local scale - can alter taxonomic composition, reduce macroinvertebrate diversity and eliminate sensitive taxa.

Sandin and Johnson (2004) observed that microscale (substratum, riparian vegetation and some chemical parameters) and macroscale (landscape) variables explained the among-site variance of benthic macroinvertebrate assemblages, suggesting that both types of variables must be considered during the creation of biomonitoring programs and conservation measures for streams and rivers.

Callisto et al. (2002) developed a Rapid Assessment Protocol based on water and sediment characteristics, land uses at the margins, erosion and silting processes, riparian forest and other parameters. These parameters were used to classify the degree of environmental preservation of two rivers in Rio de Janeiro and Minas Gerais states, and were successfully applied by students and persons trained in river ecology.

Although the literature describes many impacts where agricultural land use and biodiversity losses are inter-related, there are not many studies on the relationship between landscape and water quality, using the macroinvertebrate community as a bioindicator.

This study assessed the water quality of two rivers located near agricultural areas of the Mogi-Guaçu watershed in São Paulo, Brazil.

\section{Material and Methods}

The Mogi-Guaçu watershed covers the southeast portion of Minas Gerais State and northeast portion of São Paulo State. It is an eight order watershed and its total drainage area is $17,460 \mathrm{~km}^{2}$. At the study area, the following crops are cultivated: orange, banana, coffee and eucalyptus. These crops surround the course of the Itupeva and Oriçanga rivers. For one year, water and sediment samples were collected from four sites, of which two were river 
sites with relatively preserved riparian areas (ITUP 1 and ORIC 1), whereas the other two sites had no riparian areas at all (ITUP 2 and ORIC 2). Two of the sites were located at first order river sections of the Itupeva (ITUP 1) and Oriçanga (ORIC 1) rivers; the other sites were at second (ITUP 2) and third order (ORIC 2) river sections (Figure 1).

Site "Itupeva 1" (ITUP 1) (22.07’06"(S) $\left.46^{\circ} 58^{\prime} 16^{\prime \prime}(\mathrm{W})\right)$ was located in a farm with banana and orange crops. It is a first order river section with very well-preserved riparian forest, despite being located inside a farm. The bottom sediment consisted of pebbles and riffle litter. Site "Itupeva 2" (ITUP 2) (22 $05^{\prime} 24^{\prime \prime}(\mathrm{S}) 46^{\circ} 58^{\prime} 58^{\prime \prime}$ (W)) is a second order river section and has no riparian forest at all; the bottom sediment was dominated by sand and some pool litter areas. Site ITUP 2 receives orange crop effluents and we sometimes observed cattle inside the stream during the sampling period, what could increase nutrient concentrations due to animal defecation.

Site “Oriçanga 1" (ORIC 1) (22 ${ }^{\circ} 14 ' 15^{\prime}$ "(S) $\left.46^{\circ} 56^{\prime} 08^{\prime \prime}(\mathrm{W})\right)$, is a second order river section with relatively well-preserved riparian forest, but there was a small coffee crop in its surrounding area. Its bottom sediment was comprised of riffle and pool litters, as well as some pebbles. Site "Oriçanga 2" (ORIC 2) (22006'50"(S) 46 50'28”(W)) is a third order river section, and its riparian area is very disturbed or absent along this stream. There was also an eucalyptus plantation near the site. The bottom sediment was very uniform, comprised of sand and a small amount of pool litter, without any retention mechanisms.

The environmental integrity degree of sampling sites were determined according to the rapid protocol developed by Callisto et al. (2002) and modified from the USEPA.

Physico-chemical analyses were performed bimonthly for all sites. The following water quality parameters were determined using a HORIBA model U-10 probe and a YSI (Yellow Springs Incorporated) Model 6820 probe: temperature $\left({ }^{\circ} \mathrm{C}\right)$, dissolved oxygen (D.O. \% saturation and $\mathrm{mg} / \mathrm{L}$ ), redox potential (ORP $\mathrm{mV}$ ), $\mathrm{pH}$, salinity (ppt), specific electric conductivity $(\mathrm{mS} / \mathrm{cm})$, turbidity (UNT), total dissolved solids $(\mathrm{g} / \mathrm{L})$, nitrate $\left(\mathrm{NO}_{3}^{-} \mathrm{mg} / \mathrm{L}\right)$, non-ionized ammonia $\left(\mathrm{NH}_{3} \mathrm{mg} / \mathrm{L}\right)$, and ammonium $\left(\mathrm{NH}_{4}^{+} \mathrm{mg} / \mathrm{L}\right)$. Some measurements were made at the laboratory, using a $\mathrm{HACH}$ Model DR 2000 spectrophotometer to determine the following parameters: total phosphorus $(\mathrm{mg} / \mathrm{L})$, dissolved phosphorus $(\mathrm{mg} / \mathrm{L})$. We also measured chlorophyll a concentrations by methanol and acetone extraction (MARKER et al., 1980). Fecal and total coliforms were also counted in the field using bacteriological tapes (TECNOBAC).

Benthic macroinvertebrates were sampled with a Surber sampler with $250 \mu \mathrm{m}$ mesh size and an area of $0.16 \mathrm{~m}^{2}$. Four samples were taken of each substrate type (e.g., riffle litter, pool litter, sand, stones). The samples were identified and taken to the laboratory

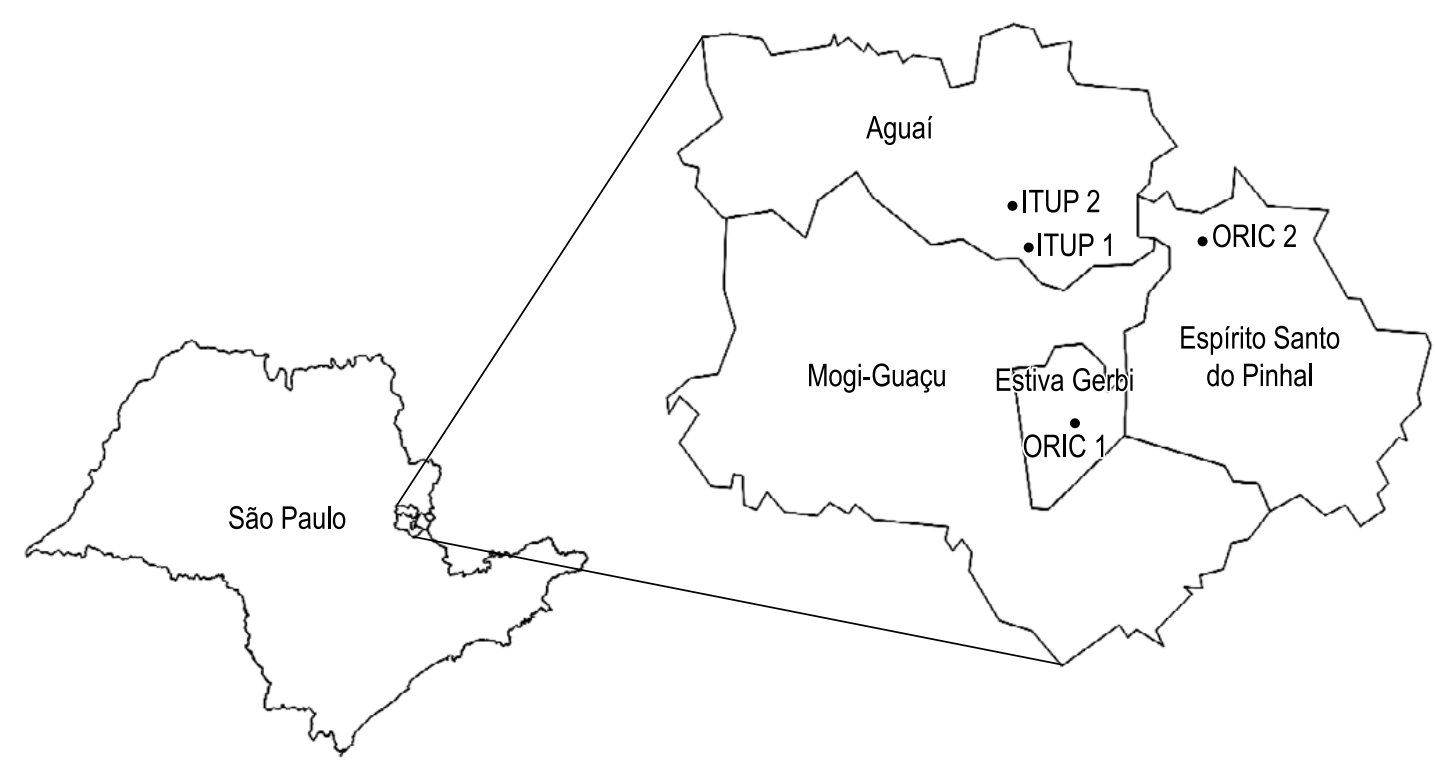

Figure 1. Location of the Pardo Mogi river basin and the four stream sampling sites (ITUP 1, ITUP 2, ORIC 1 and ORIC 2), State of São Paulo, Brazil. 
in plastic bags. At the Embrapa Environment laboratory, the samples were placed in buckets with hydrogen peroxide. In order to prolong the life time of animals and make the sorting process easier, the samples were washed on sieves with the same mesh size as the Surber sampler. After that, the samples were placed on transillumination trays for pre-sorting. Then, the samples were fixed in $80 \%$ alcohol and observed under a stereoscopic microscope. We used the following taxonomic keys to identify specimens to the family level: Pérez (1988), Angrisano (1995) and Merritt and Cummins (1996).

The metrics used for assessing benthic macroinvertebrate data were: total number of individuals, total number of families, $\%$ Chironomidae, \% EPT (Ephemeroptera, Plecoptera, Trichoptera), Margalef richness index $\left(S_{\text {Margalef }}=\right.$ number of families - 1/LN (total number of individuals)), Shannon diversity index $\left(\mathrm{H}^{\prime}\right)$, Pielou evenness index $(\mathrm{J}=\mathrm{H} / \log S$, where $S$ is the number of taxonomic units), and BMWP-CETEC/ ASPT biotic index (Junqueira and Campos, 1998). Principal Component Analysis (PCA) was applied in order to analyze sites $v s$. taxa and sites $v$ s. physicochemical parameters (Past Statistical Software, 2.02 - Hammer et al., 2001).

Soil losses were measured by the USLE Universal Soil Loss Equation (Wischmeier and Smith, 1958) (Equation 1).

$$
A=R \text { K L S C P }
$$

\section{where:}

$A=$ average annual soil loss (specific erosion);

$S=$ slope;

$\mathrm{R}=$ rainfall erosivity factor;

$\mathrm{C}=$ cropping management factor (vegetation cover);

$\mathrm{K}=$ soil erodibility factor;

$\mathrm{P}=$ anthropic factor (conservation practices);

$\mathrm{L}=$ topographic factor (slope length).

\section{Results}

The scores of environmental integrity for the four sampling sites were, in descending order: ITUP 1 (38 points); ORIC 1 (36 points); ITUP 2 (24 points); and ORIC 2 (18 points). According to this classification, sites ITUP 1 and ORIC 1 are considered natural or minimally disturbed sites. On the other hand, sites ITUP 2 and ORIC 2 are characterized as disturbed sites with anthropogenic changes (mainly deforestation of the riparian forest and siltation) (Callisto et al., 2002).

A total of 5,741 benthic macroinvertebrates distributed across 52 families were sampled from the Itupeva and Oriçanga rivers. Chironomidae was present at all sites; however Perlidae (Plecoptera), Naucoridae and Veliidae (Hemiptera) were present only at minimally disturbed sites (ORIC 1 and ITUP 1).

The greatest richness was observed at site ORIC 1, with 37 families of benthic macroinvertebrates, whereas the poorest site was ITUP 2, with 11 families present. The highest \% EPT was observed at site ORIC 2, which was an unexpected result, as EPT families normally prefer minimally disturbed sites. The families that elevated this metric at ORIC 2 were: Leptoceridae (Trichoptera), Leptohyphidae and Baetidae (Ephemeroptera). The Shannon-Weaver index did not present expected values. Despite the highest value being found at ITUP 1 , sites ITUP 2 and ORIC 2 presented almost the same value as ITUP 1, a minimally disturbed site The lowest diversity and evenness values were found at ORIC 1, what was not expected according to the protocol by Callisto et al. (2002). Site ITUP 1 presented a significant number of shredders, such as Phylloicus (Calamoceratidae: Trichoptera), which was not verified at other sites (Table 1).

Physico-chemical analysis revealed almost no significant alteration in measured variables, according to the limits established in CONAMA

Table 1. Biotic metrics of benthic macroinvertebrate communities of Itupeva and Oriçanga river sites.

\begin{tabular}{|c|c|c|c|c|}
\hline Biotic Metrics & ITUP 1 & ITUP 2 & ORIC 1 & ORIC 2 \\
\hline No. individuals & 1472 & 790 & 2864 & 615 \\
\hline No. families & 37 & 20 & 40 & 24 \\
\hline$S_{\text {Margalef }}$ & 4.94 & 2.86 & 4.90 & 3.51 \\
\hline$\%$ Shredders & 21.00 & 0.51 & 0.80 & 3.90 \\
\hline$\%$ Chironomidae & 39.61 & 46.88 & 65.99 & 34.05 \\
\hline$\%$ EPT & 28.06 & 5.99 & 8.1 & 14.16 \\
\hline BMWP-CETEC/ASPT & 3.57 & 3.95 & 3.85 & 4.54 \\
\hline H' (Shannon-Weaver index) & 0.825 & 0.824 & 0.657 & 0.807 \\
\hline $\mathrm{J}$ (Pielou index) & 0.526 & 0.633 & 0.410 & 0.585 \\
\hline
\end{tabular}


Resolution Number 357/05 (Brasil, 2005). Dissolved oxygen ranged from $4.23 \mathrm{mg} / \mathrm{L}$ at ITUP 1 to $9.65 \mathrm{mg} / \mathrm{L}$ at ORIC 2, with special note to the distinctive results of ORIC 1 which presented the highest dissolved oxygen concentration, i.e. $9.26 \mathrm{mg} / \mathrm{L}$ (Tables 2 and 3).

Table 4 shows the loss of soil by erosion in the studied watersheds, near the sampled sites. In an assessment of median soil losses, we verified that soil loss was most intense at sites where sugarcane, annual crops and fruit cultures prevail. According to Wischmeier and Smith (1958), soil loss at ORIC 1 and ORIC 2 is classified as moderate, whereas soil loss at ITUP 1 and ITUP 2 is low and very low, respectively.

For benthic macroinvertebrate families, the first axis of the Principal Component Analysis (PCA) showed that families like Calamoceratidae and Perlidae are at an opposite side from Simuliidae, Bivalvia and Leptohyphidae families, suggesting the separation of sensitive families from tolerant ones (Figure 2a). Considering sampling sites, season was not important, as sites were grouped independently of month (Figure 2b).

For physico-chemical parameters, PCA indicated that $\mathrm{pH}$, turbidity and dissolved oxygen were at an opposite side from total and fecal coliforms (Axis 1), which are respectively related to the most preserved site (ITUP 1) and the disturbed site (ITUP 2) (Figure 3a). Sampling sites were not separated according to axis 1 , but site ITUP 1 at May was an outlier (Figure 3b).

\section{Discussion}

Leptoceridae is considered sensitive to organic pollution, but Baetidae is more tolerant (De Pauw and Heylen, 2001). Furthermore, no Plecoptera specimens were sampled at ORIC 2 , what is expected for a disturbed site because of the high dissolved oxygen concentrations required by plecopterans. On the other hand, despite anthropogenic impacts found at ORIC 2, the biotic metrics for this site are not very different compared to ORIC 1 (Table 1).

The BMWP-CETEC/ASPT biotic index and Margalef richness index presented expected values, i.e., higher values of these indexes were calculated for the better-preserved sites (ORIC 1 and ITUP1), as compared to disturbed sites (ORIC 2 and ITUP 2).

An hypothesis to explain the low diversity and evenness indices found at site ORIC 1 is the presence of a sugarcane plantation near this site, suggesting that the riparian forest is not preventing erosion or inflow of chemical effluents from agricultural activities, which could result in less aquatic biodiversity. However, pesticide chemical analysis would be needed to confirm this hypothesis.

The significant number of shredders at site ITUP 1 corroborates the study of Nislow and Lowe (2006), who reported a negative correlation between shredder abundance and deforestation of spring water riparian areas. This trichopteran family uses leaves and sticks that fall from trees to feed themselves and build shelters. Phylloicus larvae build their shelters with fragments of leaves, thus being particularly sensitive to deforestation. The highest contribution of EPT families was observed at ITUP 1 and the lowest value at ITUP 2. This could be related to good riparian forest preservation at ITUP 1 - which is essential for the survival and presence of shredders, specially the Calamoceratidae (Trichoptera), as mentioned before - and also to the elevated dissolved oxygen concentrations in the
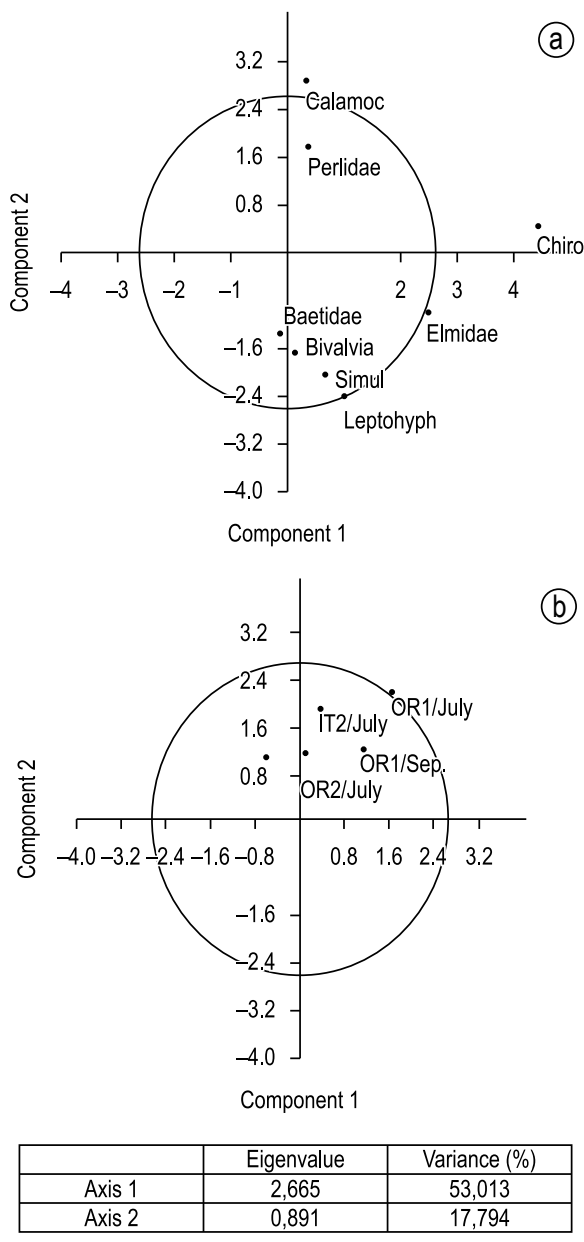

Figure 2. Principal Component Analysis (PCA) for benthic macroinvertebrates community. a) macroinvertebrate families; b) sampling sites. 
Table 2. Physicochemical parameters of water quality at Itupeva river (sites ITUP 1 and ITUP 2).

\begin{tabular}{|c|c|c|c|c|c|c|}
\hline \multirow[t]{2}{*}{ Variables } & \multicolumn{3}{|c|}{ ITUP 1} & \multicolumn{3}{|c|}{ ITUP 2} \\
\hline & Mean & Maximum & Minimum & Mean & Maximum & Minimum \\
\hline Depth (m) & 0.12 & 0.20 & 0.10 & 0.16 & 0.20 & 0.10 \\
\hline Temperature $\left({ }^{\circ} \mathrm{C}\right)$ & 22.3 & 23.6 & 20.1 & 21.7 & 24.7 & 17.5 \\
\hline $\mathrm{pH}$ & 4.86 & 6.10 & 4.09 & 5.53 & 6.22 & 4.79 \\
\hline Specific Conductivity (mS/cm) & 0.006 & 0.010 & 0.001 & 0.011 & 0.017 & 0.006 \\
\hline Total dissolved solids $(\mathrm{g} / \mathrm{L})^{*}$ & 0.004 & 0.006 & 0.001 & 0.007 & 0.011 & 0.004 \\
\hline Turbidity (UNT) & 12 & 25 & 3 & 14 & 24 & 4 \\
\hline Dissolved Oxygen (mg/L) & 6.04 & 7.80 & 4.23 & 6.00 & 6.96 & 5.40 \\
\hline Salinity (ppt) & 0.00 & 0.00 & 0.00 & 0.00 & 0.00 & 0.00 \\
\hline Non-ion ammonia $\left(\mathrm{NH}_{3} \mathrm{mg} / \mathrm{L}\right)$ & 0.02 & 0.05 & 0.00 & 0.03 & 0.06 & 0.00 \\
\hline Nitrate $\left(\mathrm{NO}_{3}^{-} \mathrm{mg} / \mathrm{L}\right)$ & 0.7 & 1.8 & 0.4 & 1.0 & 2.2 & 0.0 \\
\hline Nitrite $\left(\mathrm{NO}_{2}^{-} \cdot \mathrm{mg} / \mathrm{L}\right)$ & 4 & 9 & 1 & 3 & 8 & 1 \\
\hline Total $\mathrm{P}\left(\mathrm{PO}_{4}^{--} \mathrm{mg} / \mathrm{L}\right)$ & 0.22 & 0.40 & 0.10 & 0.22 & 0.34 & 0.01 \\
\hline Dissolved $\mathrm{P}\left(\mathrm{PO}_{4}^{-} \mathrm{mg} / \mathrm{L}\right)$ & 0.06 & 0.11 & 0.01 & 0.09 & 0.13 & 0.01 \\
\hline Chlorophyll a $(\mu \mathrm{g} / \mathrm{L})$ & 15.70 & 43.76 & 0.00 & 39.54 & 156.21 & 3.06 \\
\hline Total coliforms (UFC/100 mL) & 120 & 720 & 0 & 260 & 1560 & 0 \\
\hline Fecal coliforms (UFC/100 mL) & 70 & 420 & 0 & 60 & 360 & 0 \\
\hline
\end{tabular}

*Values calculated from the specific conductivity $(\mathrm{mS} / \mathrm{cm})$ results obtained with the HORIBA U10 probe.

Table 3. Physicochemical parameters of water quality at Oriçanga river (sites ORIC and ORIC 2).

\begin{tabular}{|c|c|c|c|c|c|c|}
\hline \multirow[t]{2}{*}{ Variables } & \multicolumn{3}{|c|}{ ORIC 1} & \multicolumn{3}{|c|}{ ORIC 2} \\
\hline & Mean & Maximum & Minimum & Mean & Maximum & Minimum \\
\hline Depth (m) & 0.23 & 0.59 & 0.10 & 0.17 & 0.24 & 0.10 \\
\hline Temperature $\left({ }^{\circ} \mathrm{C}\right)$ & 21.0 & 23.7 & 18.8 & 21.3 & 23.8 & 17.0 \\
\hline $\mathrm{pH}$ & 6.60 & 7.36 & 5.72 & 6.83 & 7.45 & 6.32 \\
\hline Specific conductivity (mS/cm) & 0.086 & 0.129 & 0.049 & 0.056 & 0.066 & 0.042 \\
\hline Total dissolved solids (g/L)* & 0.056 & 0.084 & 0.032 & 0.036 & 0.043 & 0.027 \\
\hline Turbidity (UNT) & 14 & 48 & 3 & 27 & 81 & 10 \\
\hline Dissolved Oxygen (mg/L) & 7.22 & 9.26 & 4.82 & 7.03 & 9.65 & 5.00 \\
\hline Salinity (ppt) & 0.02 & 0.05 & 0.00 & 0.01 & 0.03 & 0.00 \\
\hline Non - ion ammonia $\left(\mathrm{NH}_{3} \mathrm{mg} / \mathrm{L}\right)$ & 0.05 & 0.09 & 0.01 & 0.04 & 0.07 & 0.00 \\
\hline Nitrate $\left(\mathrm{NO}_{3} \cdot \mathrm{mg} / \mathrm{L}\right)$ & 2.7 & 4.0 & 1.3 & 1.8 & 2.6 & 0.4 \\
\hline Nitrite $\left(\mathrm{NO}_{2}^{-} \mathrm{mg} / \mathrm{L}\right)$ & 2 & 4 & 0 & 1 & 3 & 0 \\
\hline Total $\mathrm{P}\left(\mathrm{PO}_{4}^{--} \mathrm{mg} / \mathrm{L}\right)$ & 0.32 & 0.61 & 0.15 & 0.29 & 0.48 & 0.11 \\
\hline Dissolved $\mathrm{P}\left(\mathrm{PO}_{4}^{-} \mathrm{mg} / \mathrm{L}\right)$ & 0.13 & 0.27 & 0.02 & 0.10 & 0.16 & 0.04 \\
\hline Chlorophyll a $(\mu \mathrm{g} / \mathrm{L})$ & 4.16 & 10.83 & 0.00 & 6.39 & 26.57 & 0.61 \\
\hline Total coliforms (UFC/100 mL) & 40 & 240 & 0 & 150 & 900 & 0 \\
\hline Fecal coliforms (UFC/100 mL) & 40 & 240 & 0 & 70 & 420 & 0 \\
\hline
\end{tabular}

* Values calculated from the specific conductivity $(\mathrm{mS} / \mathrm{cm})$ results obtained with the HORIBA U10 probe.

water, which helps Plecoptera to survive. This result was expected, as EPT orders are known for their sensitivity to environmental disturbances, such as silting and nutrient enrichment.

The greatest proportion of Chironomidae was observed at ORIC 1 and the lowest at ORIC 2. The Chironomidae family is considered very tolerant to organic pollution. In spite of this, when ORIC 1 and ORIC 2 were compared, the less disturbed site (ORIC 1) presented unexpected results, as " $\%$ EPT" and "\% Chironomidae" were respectively lower and higher than the impacted site (ORIC 2) (Table 1). This was confirmed by the PCA analysis, where separation between disturbed and preserved sites was not observed.

The PCA distinguished tolerant and sensitive macroinvertebrate families, but this was not related to the sampling sites, suggesting that antropogenic 
disturbances, were not big enough to differentiate sites.

Among the many physical and chemical variables measured, the values found for specific conductivity $(\mathrm{mS} / \mathrm{cm})$ and total dissolved solids $(\mathrm{g} / \mathrm{L})$ may also be related to the mulching, soil conservation and agricultural practices presently adopted in this region. It was possible to establish many direct associations between turbidity and amount of solids suspended in the water and accumulated in the bottom sediment of the sampled sites located downstream from the sources of tributaries of rivers Itupeva and Oriçanga. A preliminary analysis of the results showed an increase in specific conductivity $(\mathrm{mS} / \mathrm{cm})$ and total dissolved solids between nonimpacted sampling sites (ITUP 1 and ORIC 1), respectively $0.001 \mathrm{mS} / \mathrm{cm}$ to $0.129 \mathrm{mS} / \mathrm{cm}$ and $0.001 \mathrm{~g} / \mathrm{L}$ to $0.084 \mathrm{~g} / \mathrm{L}$; however, these results must be interpreted taking other variables into

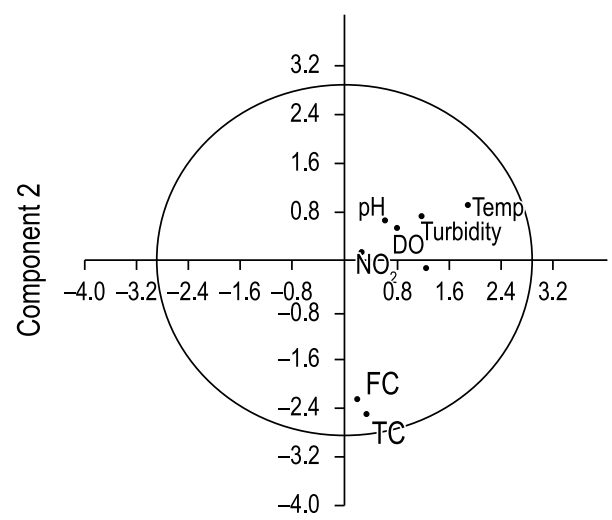

Component 1

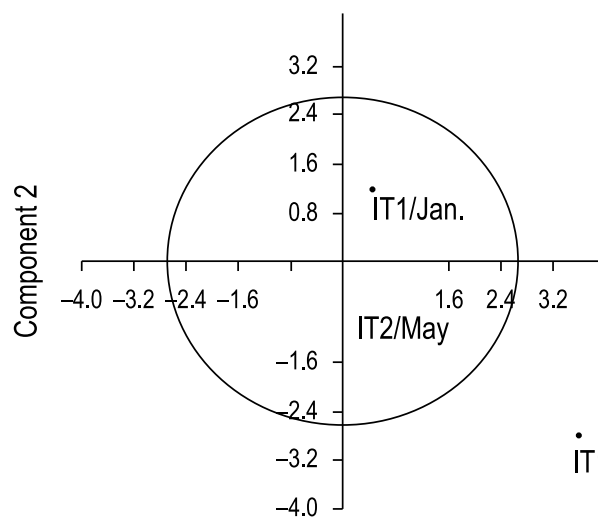

Component 1

\begin{tabular}{|c|c|c|}
\hline & Eigenvalue & Variance (\%) \\
\hline Axis 1 & 1,358 & 59,966 \\
\hline Axis 2 & 0,794 & 35,061 \\
\hline
\end{tabular}

Figure 3. Principal Component Analysis (PCA) for physico-chemical analysis. a) physico-chemical parameters; b) sampling sites, FC: Total Coliforms, FC: Fecal Coliforms, physico-chemical parameters. account, also making the pertinent associations with agricultural practices adopted in the region and their effects on the benthic community (Tables 2 and 3). For instance, considerations should include whether soil conservation and riparian forest preservation techniques are being adopted. Still, the high specific conductivity found at ORIC 1 may explain some environmental disturbance indicators obtained through biological measurements, such as the low EPT percentage (proportion of pollutionsensitive organisms) and high Diptera percentage (proportion of organisms that generally tolerate pollution). This means that ORIC 1 cannot accurately be considered as a reference site, because its alterations in both physico-chemical parameters and the benthic community indicate some level of environmental degradation, which may be attributed to the proximity of the studied stream to a coffee plantation and cattle farming activities. Vivan et al. (2009) reported the effects of sediment disposal on macroinvertebrate associations and community parameters such as abundance, taxa richness and Shannon-Weaver diversity index, which presented significantly reduced values after sediment disposal.

PCA showed that for physico-chemical parameters, seasons were not relevant: the sites were grouped independently of month, with the exception of ITUP 1 at May. Moreover, ITUP1 was not isolated; this is confirmed by Table 2 , where some important parameters, like dissolved oxygen, turbidity, nitrite, and total phosphorus did not differ between sites ITUP 1 and ITUP 2 .

The high degree of silting found during the rainy months in Itupeva river at both sites, sampled downstream to the agricultural activities, indicates that an accentuated silting process is taking place at these sites, easily observed by the amount of sand banks along the river channel. However, this change in the river-bottom substrate, replacing thick particles by thin ones, results in a substitution of species in the benthic community and could also be attributed to the River Continuum Concept (Vannote et al., 1980). Environments comprised mainly of thin and silty sediments usually present a larger abundance of filtering and collecting organisms, to the detriment of predators and shredders.

Differences in soil loss between the studied watersheds were primarily associated with topographic differences between these two areas. The mean slope at ORIC 1 and ORIC 2 is $10 \%$, whereas at ITUP 1 and ITUP 2 the mean slope 
Table 4. Soil loss by erosion and category of land use at sites located in the Oriçanga and Itupeva river watersheds. NM - not measured. Values measured by the USLE - Universal Soil Loss Equation.

\begin{tabular}{lcccc}
\hline \multirow{2}{*}{ LAND Use } & Oric 1 & Oric 2 & Itup 1 & Itup 2 \\
\cline { 2 - 5 } & \multicolumn{4}{c}{${\text { Mg.ha- }{ }^{-1} \text {. year }}^{-1}$} \\
\hline Forest & 0.7 & 0.5 & 0.1 & 0.1 \\
Silviculture & $\mathrm{NM}$ & 6.3 & $\mathrm{NM}$ & $\mathrm{NM}$ \\
Pasture & 5.5 & 3.1 & $\mathrm{NM}$ & 3.8 \\
Coffee & 6.8 & 5.3 & $\mathrm{NM}$ & $\mathrm{NM}$ \\
Fruticulture & $\mathrm{NM}$ & 4.8 & 2.2 & 1.8 \\
Sugar cane & 15.3 & 17.8 & 5.6 & 6.2 \\
Annual cultures & $\mathrm{NM}$ & 11.5 & 16.4 & 25.1 \\
Mean & 6.0 & 8.8 & 3.5 & 2.3 \\
\hline
\end{tabular}

is $2.8 \%$. The highest soil losses were observed in annual and sugarcane crop areas. Such losses are associated with intense mechanization in these areas, as well as differences in topography between ORIC 1-ORIC 2 and ITUP 1-ITUP 2. Thus, the high water turbidity, observed mainly in the Oriçanga river, was also in accordance with the greater soil loss by erosion observed in areas where sugarcane and annual cultures are grown. According to the collected data, ORIC 2 presented the highest mean soil loss value, which can explain the elevated turbidity values at this site.

\section{Conclusion}

This study found that many factors are influencing the studied benthic macroinvertebrate communities and that land use plays an important role in agricultural areas. Statistical analysis showed between-sites differences in macroinvertebrate families and physico-chemical parameters, but the differences were subtle and not so evident to separate sampling sites according to their environmental integrity.

The soil loss calculated for each sampling site showed higher values in the river Oriçanga, which may have contributed to greater input of organic pollutants at the rainy season, resulting in worsening of water quality at these sites. Our soil loss measurements suggest that agricultural activities in the Mogi-Guaçu watershed study area must consider the slope of areas near aquatic ecosystems, due to the potential environmental impacts to these systems, especially erosion and inflow of polluted effluents.

\section{Acknowledgements}

This work was supported by grants from FAPESP and Embrapa Environment.

\section{References}

ANGRISANO, EB. 1995. 'Insecta Trichoptera'. In LOPRETTO, EC. and TELL, G., ed. Ecossistemas de aguas continentales: metodologias para su estúdio. vol. III. La Plata, Argentina: Ediciones Sur. p. 1199-1237.

BRASIL. 2005. Resolução CONAMA no 357, de 17 de março de 2005. Dispóe sobre a classificação dos corpos de água e diretrizes ambientais para o seu enquadramento, bem como estabelece as condiçóes e padrooes de lançamento de efluentes, e dá outras providencias. Diário Oficial da União, Brasília.

CAllisto, M., FERREIRA, W., MORENO, P., GOULART, MDC. and PETRUCIO, M. 2002. Aplicação de um protocolo de avaliaçáo rápida da diversidade de habitats em atividades de ensino e pesquisa (MG-RJ). Acta Limnologica Brasiliensia, vol. 14 , no. 1 , p. 91-98.

CORBI, JJ. and TRIVINHO-STRIXINO, S. 2006. Influence of taxonomic resolution of stream macroinvertebrate communities on the evaluation of different land uses. Acta Limnologica Brasiliensia, vol. 18 , no. 4, p. 469-475.

DE PAUW, N. and HEYLEN, S. 2001. Biotic index for sediment quality assessment of watercourses in Flanders, Belgium. Aquatic Ecology, vol. 35, p. 121-133.

DUDGEON, D. 2006. the impacts of human disturbance on stream benthic invertebrates and their drift in North Sulawesi, Indonesia. Freshwater Biology, vol. 49, p. 721-734.

HAMMER, Ø., HARPER, DAT. and RYAN, PD. 2001. PAST: paleontological statistics software package for education and data analysis. Palaeontologia Electronica, vol. 4, no. 1. Available from: <http://palaeo-electronica. org/2001_1/past/issue1_01.htm>.

HARDING, JS., CLAASSEN, K. and EVERS, N. 2006. Can forest fragments reset physical and water quality conditions in agricultural catchments and act as 
refugia for forest stream invertebrates? Hydrobiologia, vol. 568, p. 391-402.

IWATA, T., NAKANO, S. and INOUE, M. 2003. Impacts of past riparian deforestation on stream communities in a tropical rainforest in Borneo. Ecological Applications, vol. 13, p. 461-473.

JUNQUEIRA, VM. and CAMPOS, SCM. 1998. Adaptation of the "BMWP" method for water quality evaluation to Rio das Velhas watershed (Minas Gerais, Brazil). Acta Limnologica Brasiliensia, vol. 10, no. 2, p. $125-135$.

LORION, CM. and KENNEDY, BP. 2009. Relationships between deforestation, riparian forest buffers and benthic macroinvertebrates in neotropical headwater streams. Freshwater Biology, vol. 54, no. 1, p. 165-180.

MARKER, AFH., NUSCH, EA., RAI, H. and RIEMAN, M. 1980. The measurement of photosynthetic pigments in freshwaters and standardization of methods: conclusions and recommendations. Archiv für Hydrologie, no. 14, p. 91-106.

MERRITT, RW. and CUMMINS, KW., ed. 1996. An introduction to the Aquatic Insects of North America. 3rd ed. Dubuque, IA: Kendall/Hunt Publishing. $862 \mathrm{p}$.

MINSHALL, GW. 1984. Aquatic insect-substratum relationships. In (RESH, VH. and ROSENBERG, DM., ed.). The ecology of aquatic insects. New York: Praeger Scientific. p. 358-400.

NISLOW, KH. and LOWE, WH. 2009. Influence of logging history and riparian forest characteristics on macroinvertebrates and brook trout. Freshwater Biology, vol. 51, p. 388-397.

PÉREZ, GR. 1988. Guia para el estúdio de los macroinvertebrados acuáticos del Departamento de Antioquia. Bogotá, Colombia: Presencia. 217 p.

QUINN, JM., COOPER, AB., DAVIES-COLLEY, RJ., RUTHERFORD, JC. and WILLIAMSON, RB. 1997. Land use effects on habitat, water quality, periphyton, and benthic invertebrates in Waikato, New Zealand hill country streams. New Zealand Journal of Marine and Freshwater Research, vol. 31, p. 569-577.

RICHARDS, C., HARO, RJ., JOHNSON, LB. and HOST, GE. 1997. Catchment and reach-scale properties as indicators of macroinvertebrate species traits. Freshwater Biology, vol. 37, p. 219-230.

ROTH, NE., ALLAN, JD. and ERICKSON, DL. 1996. Landscape influences on stream biotic integrity assessed at multiple spatial scales. Landscape Ecology, vol. 11, p. 141-156.

SANDIN, L. and JOHNSON, RK. 2004. Local, landscape and regional factors structuring benthic macroinvertebrate assemblages in Swedish streams. Landscape Ecology, vol. 19, p. 501-514.

VANNOTE, RL., MINSHALL, GW., CUMMINS, KW., SEDELL, JR. and CUSHING, CE. 1980. The river continuum concept. Canadian Journal of Fisheries and Aquatic Science, vol. 37, p. 130-137.

VASCONCELOS, MC. and MELO, AS. 2008. An experimental test of the effects of inorganic sediment addition on benthic macroinvertebrates of a subtropical stream. Hydrobiologia, vol. 610, p. 321-329.

VIVAN, JM., DOMENICO, MD. and ALMEIDA, TCM. 2009. Effects of dredged material disposal on benthic macrofauna near Itajaí Harbour (Santa Catarina, Brazil). Ecological Engeneering, vol. 35, no. 10 , p. $1435-1443$.

WANTZEN, KM. 2006. Physical pollution: effects of gully erosion on benthic invertebrates in a tropical clear-water stream. Aquatic Conservation: Marine and Freshwater Ecosystems, vol. 16, p. 733-749.

WATERS, TF. 1995. Sediment in streams: sources, biological effects and control. Bethesda, Maryland: American Fisheries Society. American Fisheries Society Monograph, no. 7.

WISCHMEIER, WH. and SMITH, DD. 1958. Rainfall energy and its relationship to soil loss. Transactions of the American Geophysical Union, vol. 39, no. 2, p. 285-291.
Received: 22 September 2009 Accepted: 08 November 2010 